\title{
Edict in Pre-Colonial India: An Analysis from the New Haven Perspective ${ }^{1}$
}

\author{
Fozia Nazir Lone \\ School of Law, City University of Hong Kong, Hong Kong, China \\ Email: fnlone@cityu.edu.hk
}

Received 3 November 2013; revised 2 December 2013; accepted 5 January 2014

Copyright (c) 2014 by author and Scientific Research Publishing Inc.

This work is licensed under the Creative Commons Attribution International License (CC BY). http://creativecommons.org/licenses/by/4.0/

(c) (i) Open Access

\section{Abstract}

The territory of India is the locus of an ancient and deeply philosophical culture. This land not only gave birth to the epic religion of Hinduism but also to the first urban civilization, the Indus Valley Civilization. Many different kingdoms such as Mauryan Empire and Mughal Empire with customary authoritative decision practices also emerged in the Indian subcontinent. However, the impact these deep and distinct cultures, civilizations and empires have had on decision-making and official behavior in India over the decades has not been studied. This article seeks to study the notion of law/interstate law in pre-colonial India, how it was formulated during and in what way/s the process of making law was different from western traditions of law-making. To achieve this end, the New Haven methodology will be adopted. This work will also provide some preliminary conclusions in relation to Indian foreign policy which remains "formalist dualism" from ancient to current times.

\section{Keywords}

New Haven Jurisprudence; International Law; Interstate Law; Pre-Colonial India; Westphalia and Eastphalia

\section{Introduction}

In the 19th Century the doctrine of common interests in Europe was supposed to form "the standard of civiliza-

\footnotetext{
${ }^{1}$ This article is the product of ongoing New Staff Start-up Grant for Research Grant Application carried out at the City University of Hong Kong and research is titled "An Application of the New Haven School of Jurisprudence to Indian Pre-colonial Approaches to International Law”. The draft of this article was presented in a 4th New Haven Conference organized at the City University of Hong Kong (5-6 October 2012). Author wishes to acknowledge the monetary assistance provided by startup grant and also thanks the participants of 4th New Haven Conference for providing valuable comments on this paper. Notable author wishes to thank for Professor Reisman comments that assisted in amending this article.
} 
tion”. However, the Westphalian legal order ${ }^{2}$ by its interactions with non-European world imposed the "unequal, imperialist and colonial treaties" in Asia and Africa hence drawing these non-European states into the first global international system. Colonies became a part of "world-order" as "subjects" rather than "partners". It would then not be incorrect to describe the foundations of the modern international society, apart from other perceptions, as one based on a history of colonial coercion, imperialism and conviction of fear. Indeed international law is Hobbesian in character because it is based on fear and an idea to guard itself from "the anarchy of prepolitical societies outside the ordered system of European states" (Moloney, 2011: pp. 189-204). However, the general connection of "law and society" is also well known. This is clear from the Cicero's famous adage, "ubisocietas, ibiius" meaning "where a society exists, there is law", too. Thus, as Paulus notes, "the intimate connection between the existence of a society and the existence of a legal system has a long pedigree. A society relies on law to develop at least the minimum degree of cohesion inevitable for its existence; law reflects the normative state of a society and relies on it for its implementation" (Paulus, 2013).

Keeping in view these general western notions on international law/law, this work proposes to study the eastern tradition of law (authoritative decision) as used in pre-colonial India during the Mauryan Empire in an inter-

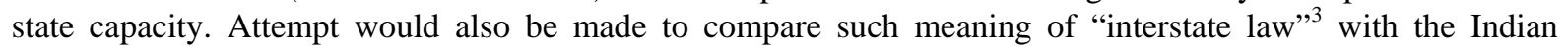
post-colonial international law and essentially western practice on international law. Essentially this study aims to explore whether there was a particular pre-colonial Indian vision of law (including interstate law), legal process, power and collectivism; whether classical Indian approaches to interstate law were liberal or non-liberal when compared to the Westphalian understanding of international law; whether under the conceptual tools of positivism, is there a gap in understanding of law between European and non-European world. In an attempt to determine answers to these very difficult questions, a possibility will be to bridge the classical, cultural, doctrinal and moral differences between Indian and Western understanding of interstate law. In attempting to answer these questions the analytical framework of the New Haven School (NHS) will be adopted (Lasswell \& McDougal, 1992). Attempt would be made to understand relations among law, society and culture in pre-colonial India in particular: perspectives in pre-colonial India (in terms of expectations and demands) and social process (in terms of values pursued and fulfilled, institutions and outcomes). Finally, in light of the arguments and materials covered, preliminary conclusions will be offered with an attempt to appraise how the pre-colonial Indian practices on interstate law bear on contemporary Indian international goals.

The jurisprudence of the NHS would assist in defragmenting and analyzing the decisions that were made by the elites in the pre-colonial social process to visualize/predict whether they could be compared with European international law. The irony is that positivist international law, which focuses on rules and regulations, does not provide the methodology to study legal traditions in the pre-colonial non-western civilizations, such as India. When discussing the theories of international law such as naturalism, positivism, Grotian School etc., there is no or little mention of the east, which may connote that eastern civilizations have not contributed to European international law at all. This article hence endeavors to highlight the great work of the eastern scholar Kautilya, who existed in 4th Century. Idea is to demonstrate concept of interstate law in the east. In order to put the precolonial understanding of interstate law in perspective a brief colonial and post-colonial history will also be reviewed with an aim to establish whether such interstate law and foreign policy remains unchanged or not.

\section{Brief Contextual Framework of Colonial and Post-Colonial India}

As the last Mughal ruler Aurangzeb lost his grip over his Empire, his subordinate rulers started to assert their independence (Menon, 1961: p. 2) which created Princely States. It was during the 1600s’ British started trading in the Indian subcontinent an East India Company (EIC) along with the other European companies (Kulke \&

\footnotetext{
${ }^{2}$ Westphalian legal order also demonstrates a fundamental shift in the international Community "from a hierarchical order based on the recognition of authorities above the States to a horizontal system characterized by the coexistence of a multiplicity of territorially defined autonomous entities and sustained by a new type of law operating between rather than above the members of the system”. See Rainer Grote, Westphalian System in Max Planck Encyclopedia of Public International Law, March 2013, http://opil.ouplaw.com)

${ }^{3}$ Author intends to use term' interstate' to mean law/practices Involving two or more states that was created in precolonial India during the Mauryan Period. It must be borne in mind that in precolonial India there was no concept of international law a term which was coined by the English philosopher Jeremy Bentham (1748-1832) which was then also interchangeable use with terms such as public international law and law of nations to mean and refer to legal rules, norms, and standards that were to apply in the dealings of international actors prominently between the sovereign states.
} 
Rothermund, 2004). The EIC established their foothold both by negotiation and confrontation with the Princes. It was only in 1773 that trading British EIC came under the direct control of the British Parliament. ${ }^{4}$ By 1833 Charter Act Company assumed the function of Government of India (GOI) (Menon, 1961: p. 8). British India was managed at the imperial government in London through Secretary of State for India and the Viceroy, who remained head of the GOI. After the 1857 Mutiny, the remaining powers of EIC were transferred to the Crown. ${ }^{5}$ The expansionism came to a halt by Queen Victoria's Proclamation of 1858 stating: "we desire no extension of our present territorial possessions... we shall respect the rights, dignity and honour of native princes as our own” (Menon, 1961: p. 9). This left 584 Princely States scattered across the British India (Miller, 1968: p. 42). The rest of the territory was ruled directly by the British Crown as a colony of the United Kingdom, and officially known after 1876, as the Empire of India. ${ }^{7}$

The real drama unfolded when the British colonial masters agreed to grant independence to British India, the issue immediately arose how to divide the territory between Hindus and Muslims. Viceroy Mountbatten was unable to persuade the National Congress leader, Jawaharlal Nehru and Muslim League leader, Ali Mohammad Jinnah to agree to the creation of a single nation of India. The two-nation theory and the bloodshed of 1946-47, justified the partition of British India. It was premised on the notion of Jinnah who was of the view that National Congress does not represent the interests of India’s largest minority, the Muslims (Guha, 2007: p. 9). As freedom came to India and Pakistan in August 1947 with it were born two polarized nations that have since embroiled in never ending wars over territory of Kashmir, which was a Muslim majority Princely State ruled by the Hindu Ruler. On 30 January 1948, Gandhi was assassinated by Hindu extremist was of the view that "his main provocation was the Mathama's constant and consistent pandering to the Muslims', culminating in his last pro-Muslim fasting [which] at last goaded me to the conclusion that the existence of Gandhi should be brought to an end immediately" (Guha, 2007: p. 22).

Dispute over Kashmir was taken by India to UN under Chapter VI and several resolutions were passed aiming to demilitarize this area and conduct plebiscite. However it never happened and now both India and Pakistan are aiming to resolve it bilaterally without any external assistance (Lone, 2009). Upon independence, India also inherited colonial territorial dispute of the McMahon Line with China. India has incorporated disputed territory into its state of Arunachal Pradesh and China claims it to be part of Tibetan territory (Carty \& Lone, 2011: p. 96) Both Kashmir and McMahon Line dispute remain unsettled and for now "status quo" is maintained on them for the sake of maintaining the "balance of power" between the nations involved. India over the years has given refuge to the Tibetan government in exile. On the other hand China has always maintained a position that Kashmir does not belong to India. So these disputes will also determine how international law will be shaped keeping in view these disputes.

Despite all the communal upheavals, poverty and cast system, India despite its oddities and idiosyncrasies somehow survived by adopting varied policies. During the Cold War, India, adopted a policy of "non-alignment" in international affairs pledging not to get drawn into the power struggle between the West (the US) and the Eastern Bloc (the Soviet Union) calling for a movement not to aligned to either side. In a 1954 speech in Colombo (Sri Lanka) Nehru's described "non-alignment" as: Mutual respect for each other's territorial integrity and sovereignty; Mutual non-aggression; Mutual non-interference in domestic affairs; Equality and mutual benefit and Peaceful co-existence. These Five Principles of Coexistence later on also controlled the relationships between India and China on its border disputes. In 1967, it also laid basis for the Association of Southeast Asian Nations (ASEAN). With the end of Cold War China's influence increased in Southeast Asia. Zhao argues that from 1990s India realized rise in the Chinese influence and recognized ASEAN's importance in terms of politics, economy, and diplomacy, and consequently launched its "Look East" policy, focus of which was how to become actively engaged in Southeast Asian affairs in the post-Cold War era (Zhao, 2007). India and ASEAN signed a free-trade agreement which is expected to raise annual trade to 60 billion dollars within seven years. ${ }^{8}$

By mid-1990s the "balance of power" became more vivid as the China-US started to improve under the Clin-

\footnotetext{
${ }^{4}$ Regulating Act of 1773 was replaced by Second Regulating Act called Pitts's India Act of 1784.

${ }^{5}$ Imperial Gazetteer of India vol. IV (1908), The Indian Empire, Administrative, 5 (Published under the authority of His Majesty's Secretary of State for India in Council, Oxford at the Clarendon Press).

${ }^{6} \mathrm{~V}$. P. Menon, (1961) The Story of the Integration of the Indian States (Orient Longmans) 9.

${ }^{7}$ Imperial Gazetteer of India vol. II (1908), The Indian Empire, Historical, 514-530 (Published under the authority of His Majesty's Secretary of State for India in Council, Oxford at the Clarendon).

${ }^{8}$ ASEAN, India sign free trade deal, Available at

http://www.channelnewsasia.com/stories/afp asiapacific business/view/448668/1/.html accessed on 13 August 2009.
} 
ton Administration. It was marked with economic cooperation and diplomacy. During this time the US passively agreed to Chinese transfer of nuclear and missile equipment and technology to Pakistan. The friendly attitude of the US with China confronted India with the prospect of US-endorsed Chinese hegemony. After September 11, South Asia assumed new prominence under the Bush Administration. This became a turning point for the US relations with Pakistan that acted as a frontline State for the US interests in the region. The Bush Administration realized India to be a major player in the global economy and started making trade links with it like the bilateral agreement on civilian nuclear cooperation between India and the US. This became an opportune time for India to draw closer to the US as both shared a "mutual unease over China's rapid rise" (Zhao, 2007). The Bush Administration on 22 September 2001 lifted the sanctions that were imposed under the terms of the 1994 Nuclear Proliferation Prevention Act following India's nuclear tests in May 1998. President Bush and Indian Prime Minister Vajpayee held their first summit in November 2001 and presented a vision for the rapid transformation of the relationship between the two countries. Subsequently this provided more space and flexibility for India to carry out its Look East policy (Zhao, 2007). During the 1990s India learnt from its economic weakness of "inward-oriented strategy of economic self-reliance through import-substitution and building heavy industries" (Baldev \& Paul, 2003: p. 99). Today, China and India are among the few nations who have joined forces to push ahead with a reactor programme. ${ }^{9}$

Nehru's vision of India was to increase its State power i.e. centralism (also called Nehruvian centralism) to control economy, politics and other issues. The centralism was not favored that was ultimately the reason for the assassination of Indira Gandhi and Rajiv Gandhi. (Dossani, 2008: p. 31) However, over years there is demise of centralism and local parties took the regional issues to national level. One such example is Hindutva movement that politicizes the Hindu faith by parties like BharatiyaJanta Party (BJP). Today, India is ailing from communal Hindu fascism and anyone who is outspoken is branded as "anti-national” (Roy, 2004: p. 14). In 1989 BJP destroyed a 400 year old mosque and replaced it with a Hindu temple and claiming a Hindu temple stood there first (Ayodhya agitation) (Dossani, 2008: p. 51). This left the Muslim community feeling second class citizens who have the second largest religious population in India and forms almost 2/3 of all the religious minorities taken together (Shahabuddin, 2001). Even the low caste Hindus (dalits) are mistreated who are now converting to Buddhism and Christianity. ${ }^{10}$

There are liberation movements going on in Indian Occupied Kashmir, Nagaland, and Bengal. This threat is doubled as India lacks a common language that can bind India together. Every Indian State speaks a different language. Hindi is an official language of India but it is spoken by only about 40 percent of population (Chaudhuri, 2009). English is used as lingua franca and only about 3 percent of India's population speaks English as their second language and it is these people who lead India's economic, industrial, professional, political, and social life (Baldridge, 2002). For these reasons India is facing a prospect of federal disintegration. The other problems are poverty, corruption, internal violent political clashes (including assassination of political leaders) and governance problems (including emergence of communism in India called Naxalism) (Dossani, 2008: p. 63). This political violence remains a serious threat to growth of democracy.

\section{The New Haven Jurisprudence}

The analytical framework of the NHS of jurisprudence could be applied for understanding of any domestic or international legal problem (Harold, Lasswell, \& McDougal, 1992; Harold, Lasswell, \& Abraham Kaplan, 1950; Harold, Lasswell, \& McDougal, 1943, McDougal, 1953; Reisman, 1992; Suzuki, 1974). In proposing their criteria for a theory about law, Myres McDougal and Harold Lasswell observed, "The comprehensiveness and realism with which an observer conceives of his major focus of attention-what he regards as law and how he locates it in its larger community context-are important because they determine how he conceives every detailed part of his study: his framing of problems, his choice of tools and procedures, and his recommendation of alternatives" (McDougal \& Lasswell, 1971). Accordingly for the NHS, law in every community is made by a continuing and comprehensive process of communication or social process. Radcliffe-Brown describes law as, "a part of the machinery by which a certain social structure is maintained. The system of laws of a particular society can only be fully understood if it is studied in relation to the social structure and inversely the under-

\footnotetext{
9“Nuclear power a proven alternative”, South China Morning Post, Oct 6, 2009, 12.

${ }^{10}$ Dalits in conversion ceremony, BBC News, 14 October 2006, Accessed on 7th November 2009.
} 
standing of the social structure requires amongst other things a systematic study of the legal institutions" (Brown, 1965, cited in Lasswell \& McDougal, 1976).

It is clear from the New Haven jurisprudential perspective authoritative decisions are inseparable components of social process and such decisions are made in response to claims about particular interactions or events in social context. This analytical framework informs us that authoritative decisions are indeed affected by a wide variety of symbiotic variables and it is these factors that project future distributions of values (such as power, wealth, enlightenment, skills, well-being, affection, respect and rectitude) among participants. Hence, choices within the civic domain is indeed the collective movement of authoritative decisions in a community that contours an inclusive public order in the sense of majority value distributions of that society. Sometimes it is possible to have state policy decisions implemented which are a product of "choices" made by the government or diplomats without considering the community-wide perspectives. Such "choices" even though they are prescriptions and exist as a formal law, from the NHS perspective they are not authoritative decisions (perhaps a bad law) although they are authoritative from the standpoint of a positivist. For NHS prescription is the projection for a community, of authoritative policy pertaining to the shaping and sharing of values and in creation of a "bad law" there is no sharing of values and decisions are made only for the gain of elites not for community. There are numerous such examples where elite international community had made decisions for a particular community, such as resolutions on the status of Mayotte, but such decisions were not acceptable to people of Mayotte who wanted to part of France. ${ }^{11}$ Lasswell \& McDougal argued that developing of alternatives in authoritative decision is better designed to secure preferred community policies which are dependent not merely upon knowledge of technical legal concepts and institutions but upon a realistic map of the effective power and other social processes that condition authoritative decision (Lasswell \& McDougal, 1976).

\section{Ancient Indian Visions on Law}

The pre-colonial history of India shows that the ancient theories of international relations and social formations date back to antiquity. In ancient India there existed concepts of sovereignty, sphere of influence, law of wars etc. which were made in response to changes in political ideas, institutions, economic patterns, social structure and practices in the social process. Various authentic works suggest that Hindu texts from some eight millennia ago passed over to generations by the method of shruti ${ }^{12}$ and later by Smritis ${ }^{13}$, which contain one of the most complete sets of law of nations and relations. Scholars have suggested that in ancient Indian all the activities were guided by the four goals of dharma (concern for social order or religion), artha (wealth), karma (pleasure) and moksa (deliverance from travails of life, or spiritualism) (Sharma, 2009). Dharma remained perhaps the central aspect of community in Ancient India (Singh \& Singh, 2009). Meaning of dharma had a very close relationship with the Hindu philosophical thought and social structure and was created for the wellbeing of all creation. Dharma was seen as the principle that is capable of preserving the universe and a symbol of duties and obligations of religious, moral, social and legal nature. Dharma was visualized as religious moral order and the king as upholder and advancer of dharma (Gonda, 1969). It is also said that "law is a branch of dharma" and that "any attempt to isolate completely any secular matter from its religious adjuncts would fail to give a comprehensive idea or proper perspective of the true juridical concepts of Hindu Law” (Penna, 1985). Hence, dharma is seen as a rule of interdependence founded on a hierarchy corresponding to the nature of things and necessary for the maintenance of social order and king was considered as a significant figure to the social order (Lingat, 1973). Sources of law were further divided into texts such as: Dharmasutras, Dharmashastras, Manu Smriti, YajinavalkyaSmriti, NaradaSmriti, Puranas, Upanishads, Arthashastra and Custom and the epics (Mahabharata and Ramayana).

\subsection{Law, Arthashastra and Kautilya}

Among the sources of Hindu law is the scholarly work of Kautilya (also called Chānakya or Vishnugupta

\footnotetext{
${ }^{11}$ United Nations Security Council resolution of 1976 recognized Comorian sovereignty over Mayotte but it was vetoed by France. The United Nations General Assembly adopted a series of resolutions on the issues up to 1995. Since 1995, the subject of Mayotte has not been discussed by the General Assembly.

${ }^{12}$ Learning by hearing, revelation.

${ }^{13}$ Meaning "what has been remembered-manuscript".
} 
370-283 BC) which is illustrative of Indian ancient thought ${ }^{14}$ on the concept of interstate law. Kautilya ${ }^{15}$ before becoming an advisor to Chandragupta was a teacher in Takșaśila, an ancient centre of learning. As the key adviser of Chandragupta Maurya (317-293 B.C), he defeated the Nanda kings, stopped the advance of Alexander's successors, and for the first time ever in the history of ancient India, united most of the Indian subcontinent into the Magadha Empire. The Mauryan Empire was vast and was the first empire in archaeologically recorded history to rule most of the Indian subcontinent with borders extending to Afghanistan (Singh \& Singh, 2009). Kautilya work makes a great advance upon the branch of State Law, i.e. a political text. His work focuses on the understanding of the Sacred Canon (or Dharmasastra) of the social order from the four castes and had respective duties (dharma) to follow. He considered the dharma (sacred duty) of a king (rajadharma) to expand the resources of his state by employing varying combinations of sam (treaty), dam (rewards) and dand (punishment).

Kautilya wrote the Arthashastra which is not a namebut a generic term. It is made up of two smaller words: artha and shastra. Arthameans "worldly gains" in a broad sense, but to simplify a bit we may translate it by "wealth". Shastra means "science". An exact translation of Arthashastra would therefore be Science of Worldly Gains. Arthashastra is the science which is the means of the attainment and protection of earthly goods and wealth for the welfare of the ruler, as he was the ultimate decision maker along with his religious advisors. It is even possible to argue that in doing so ruler was indeed fulfilling its dharma or public interest for the ultimate cosmic good. Thus, on this understanding, "worldly gain" and its science was only one of three possible goals of human life i.e. Dharma, Artha, Karma and Mosha (Brekke, 2004).

\subsection{Statecraft and Cosmic Order (Dharma)}

Kautilya's work on statecraft and polity also focused on the duties of a king and military affairs, which was for the protection of ultimate right of a ruler in its "wealth". It is to be pointed out the Arthashastra was written to make the ruler a supreme power in comparison to other kingdoms and also to generate allegiance among its subjects to double its wealth. Hence, the writings of Kautilya were well connected to the social process as described from the NHS standpoint. Singh states that Arthashastra is thoroughly grounded on Brahmanical doctrines ${ }^{16}$ and describes that it is an extraordinary work because of its practical character and its wide range of subjects and interest that gives it a unique combination of features that, in European literature, we find only separately in Aristotle, Machiavelli, and Bacon's work which were written centuries after Kautilya's work (Aiyangar, 1916: p. 35). Kautilya has been considered as the pioneer in the field of economics and political science. In the Western world, he has been referred to as the Indian Machiavelli, although Kautilya's works predate Machiavelli's by about 1800 years.

\subsection{Relation of Dharma with the Concept of Internal Sovereignty and Caste/Class System}

The conception of sovereignty was well established in the Hindu philosophy of statehood. The Hindu thinkers not only analyzed sovereignty with regard to the constituent elements in a single state; they realized that sovereignty is not complete unless it is external as well as internal, that is, unless the state can exercise its internal authority unobstructed by, and independently of, other states (Sarkar, 1919: p. 400). According to Kautilya sovereignty of a State (Rajya), was vested in the Ruler (Rajas) (Chatterjee, 1958); Spellman, (1964) but position of ruler within the State was of a peculiar nature. The ruler was a part and parcel of the caste system (varna), a social structure based on a divine hereditary division of social functions. In the four tiers caste system the first class was the Brahmans, the highest caste, while the second is vested in the rulers' or warriors' caste (kysatras). A logical consequence of this separation of power to some extent was to create an elusive secularization of the royal function in the hands of the ksatryas (Dumont, 1962) and this led further to a nonspiritual concept of the

\footnotetext{
${ }^{14}$ Other ancient indian Philosophers were Manu, Yajnavalkya, Kautilya, Vitsyayana, Tiruvalluvar and Ramanuja,

${ }^{15}$ Originally a teacher at the ancient Takshashila University, he assisted the first Maurya emperor Chandragupta's rise to power at a young age. He is credited for having played an important role in the establishment of the Maurya Empire. Chanakya served as the chief advisor to both Chandragupta and his son Bindusara. He authored the ancient Indian political treatise called Arthaśāstra. He is considered as father of the field of economics and political science in India. Chanakya is often called the "Indian Machiavelli", even though his works predate Machiavelli's by about 1800 years.

${ }^{16}$ Brahmanism meaning-the religious practices and beliefs of ancient India as reflected in the Vedas. This was the social and religious system of orthodox Hindus, especially of the Brahmins, based on a caste structure and various forms of pantheism. Also see Singh B, "The Sources of Contemporary Political Thought in India—A Reappraisal” (1964) 75 Ethics 57 at 58-59.
} 
law for the privileged two upper classes. ${ }^{17}$

Kautilya assumed that the empire would be preserved if it could be ruled by a powerful and wise ruler. A state must have a king who is the sovereign, the sole ruler of that state. He is to owe allegiance to no one. State signifies that a sovereign must have a territory over which he exercises his supremacy. So a territory over which one man ruled without allegiance to another was the idea of an independent sovereign state. For Kautilya, the king was indispensable for an empire and Kautilya maintains that the king must uphold the system of class and caste, as well as the opportunity for individuals to pursue the four stages of life (Boesche, 2002). Boesche explains, the caste system, which includes four varnas ${ }^{18}$-Brahmins (dealt with sacred knowledge), Kshatriyas (provided military force and protecting the country), Vaishyas (originally dealt with agriculture and cattle rearing, but as time went on, they became involved more with trade) and Shudras (the laboring part of society and were not regarded as members of the upper three classes).

The concept of "varna" was in essence exploitative in nature and content. The hierarchy in terms of purity meant the Brahmins claimed to be the most pure and the untouchables were seen and treated the most polluted. Kautilya's work justified the class system, i.e. the texts claiming to be the divine words of the Gods, were in fact composed by the dominant classes or interests. At the heart of Arthashastra, was a conviction that the kingdom will prosper, materially and morally, if each class does the special duty outlined by varna. In defending the system of class and caste, claimed Kautilya, the king assures "the right conduct of the world" and in this manner, the kingdom will prosper and not perish. To this end, Kautilya urged the king to use laws and, if required, force to protect the class and caste system. On the other hand, Kautilya also opined that it would be advantageous to please and be just toward the lower classes, including Shudras. Kautilya readily gave way to customs and the rules of religion on minor issues of behavior and ritual, but he subtly promoted state power, the king's supremacy, over the demands of class and religion. The remarkable feature of this system is the separation of the religious function from political power yet advocating prescription and to appear attractive to the shared religious values of the Hindu masses to the advantage of the ruler and the upper class. For the citizens such prescriptions meant that each caste has to perform the religious duties (dharma) or it would be backed by sanctions (penalized).

It is argued that from the NHS jurisprudence perspective creating classes within varnas served a pertinent purpose for the ruler so that he could exercise its internal sovereignty while performing his dharmashastra and allow his class divided masses to perform their moral religious duties. It must also be borne in mind that the current international law and the UN system aims to develop friendly relations among nations, achieve international co-operation, protect and promote human rights and act as a centre for harmonizing the actions of nations in attainment of these common ends. Hence focus of the UN system is to maintain quality of states, respect of their sovereignty and non-intervention within their domestic affairs and this is clear by Article 2 of the UN Charter 1945 which states:

All Members shall refrain in their international relations from the threat or use of force against the territorial integrity or political independence of any state, or in any other manner inconsistent with the Purposes of the United Nations-Article 2 (4)... Nothing contained in the present Charter shall authorize the United Nations to intervene in matters which are essentially within the domestic jurisdiction of any state or shall require the Members to submit such matters to settlement under the present Charter; but this principle shall not prejudice the application of enforcement measures under Chapter Vll.-Article 2(7).

Hence as in the ancient precolonial India law sovereignty even today means the supreme power of a State within its boundaries which is free from external control and influence of other states.

\subsection{Inter-Sovereign Relations (Interstate Law) and Concept of Mandala (Circle of States)}

Kautilya also discusses the ancient Indian traditions of inter-State conduct in Book VII. A systematic exposition of principles of inter-sovereign relations is an expression of the balance of power in ancient India as a means of maintaining peace among various kingdoms and polities. This can also be compared with European theologians and lawyers who tried to extricate the jus gentium from the grip of theology, including Thomas Aquinas and Grotius (Alexandrowicz, 1965-1966: p. 304). For the Maintenance of Peace, Kautilya relies on two concepts; first "six measures of a King's foreign policy" and "concept of Mandala (circle of States). According to Kautilya the Circle of States is the source of the six-fold King's foreign policy" which is to maintain peace were:

\footnotetext{
${ }^{17}$ Heterogeneity was first and foremost linguistic (as it is today), but also racial or ethnical, if we consider the differences between the Aryan North and the Dravidian South.

${ }^{18}$ Varna can be traced to Rig Veda at around 1200 BCE.
} 
peace through treaty (sandhi), war (vigraha), and neutrality (asana); and alliance (samsrya); preparatory stage for fighting or expedition (yana-marching); and peace with one ruler while at war with another (dvaidhibhavah - dual policy). Nonetheless his advice to the sovereign for subjugating the weak was by means of conciliation (Arthashastra VII, 16).

For Kautilya government was a remedy to the universal anarchy, or "the law of the fish" according to which the stronger swallows up the weaker (matsyanyaya). The answer to anarchy was danda (punishment or sanction). He also believed that if the sovereign does not use the rod, it gives rise to the law of the fish. Sovereign is honored if he uses a rod in a just way; he is despised if he is mild, and hated if he is too severe ${ }^{19}$ (Alexandrowicz, 1965-1966: p. 305). It is interesting to note that traditional Chinese philosophy was starkly different than Kautilya's Arthashastra. Two Chinese philosophical concepts of $L i$ (Confucianism) and Fa (Legalism) are significant. Scholars have compared $L i$ and Fato Natural Law and Positive Law. Perhaps $L i$ was a set of moral rules that could be used to regulate individual behavior whereas $F a$ was the ancient Chinese law particularly criminal law. Indeed a proverb about law says that "Law is meant for a base people but not for a gentleman". In Chinese traditional mindset law was an instrument of dominance and not for the protection of natural rights ${ }^{20}$ (Pan, 2011). Although there seems to be similarity between Indian and Chinese understanding of law in the context of punishment, it is to be borne in mind the basis of dharma and $\mathrm{Li} / \mathrm{Fa}$ are fundamentally different from legal and social perspective.

Kautilya's objective was to propose a minimum of principles which could diminish the threat of anarchy. These principles stimulated the gradual establishment of a code of usages and customary rules which was similar to our law of nations in its earlier stages (Alexandrowicz, 1965-1966: pp. 311-312). Prior to creation of the UN the last resort to solve disputes was a war under the "Just War theory" of St Augustine. War was seen as the attribute of statehood and conquest provided title to territory. The League of Nations (1919) put a moratorium on wars under Article 10,12, 13 and 15. Members were not allowed to resort to war without submitting disputes to "Council of League" for inquiry; hence it is clear that war was prevented not prohibited. The Kellogg-Briand Pact 1928 further condemned recourse to war. The post WWII atrocities horrified the world and hence the UN was created which not only prohibited the "use of force" but "threat to use of force". It also introduced peaceful means to solve the international disputes and focused on protection of human rights.

Alexandrowicz discussed the six measures of foreign policy and asserts that according to Kautilya, a treaty with a more powerful sovereign maintains peace while war is waged against the weaker one. The idea of neutrality is not comparable to the modern concept of neutrality but indicates an intermediary stage (neither peacenor war). Alliances are concluded to obtain the protection of a powerful ruler. Kautilya states that the purpose of the six-fold policy is to make a sovereign advance from the stage of decline to the stage of balance, andfurther to the stage of progress (Alexandrowicz, 1965-1966: pp. 307-308). Kautilya was truly Hobbesian and a cynic who visualized government as a remedy to the universal anarchy. In other words Kautilya just as Hobbes articulated law in the political realm and reasoned it to shield sovereign's vulnerability and fear. State relations were hence based on force.

Kautilya also discussed the concept of Mandala (circle of states), which is also known as an expression of the "balance of power" in ancient India. According to mandala, twelve kings usually form such a circle of states, with a hypothetical ruler, a sovereign (vijigsu) in the centre. The vijigsu is obliged to act in principle according to dharma, but in practice he relies upon expediency (artha) and security considerations to guide his conduct. His immediate neighbors are his enemies (ari) and the neighbors of his neighbors are his friends (mitra). The circle is formed with five kings in the vijigsu's front, five in his rear, along with the madhyama (the mediator) and upasina (the neutral). Sovereign (Vijigsu) maintains the balance of power within the circle of states, which acts as a guarantor of restraint on the part of the rulers. The objective of this arrangement of the circle of states was "the unification of the sub-continent under the most successful of vijigsu (sovereign), who would replace decentralization by a universal empire". In such a context, thus, negotiations between sovereigns were of immense importance, and Kautilya's advice was to negotiate "to the limit" so as to gain advantage in the "battle of wits" (mantra yudha) before resorting to force. It is clear that political pragmatism forced weaker polities to enter into alliances. To this end, envoys (duta) were employed to carry out negotiations to enter into treaties and alliances, and exchanges of envoys between different states were common [Different types of dutas as distinguished by Arthashastra at page XII]. The good example in this context is the Greek ambassador Megasthe-

\footnotetext{
${ }^{19}$ Alexandrowicz CH, “Kautilyan Principles and the Law of Nations” (1965-1966) 41 British Yearbook of International Law 301 at 305.

${ }^{20}$ PAN Junwu, Chinese Philosophy and International Law, Asian Journal of International Law, I (2011), pp. $233-248$.
} 
neswho was sent to the court of Chandragupta Maurya (Nanda, 1991). In the fourth century B.C. Seleucus Nicator wrote four books of Indica, of which only fragments remain. These have been translated into English and contain information about the emperor, his court, the civil service and the caste system as well as other details (Stein, 1921). It is to be noted that British Empire used a similar model called buffer system to maintain the balance of power and maintain control of their colonial territories when surrounded by other powerful colonial nations (Turmanidze, 2009).

The pressure within the circle of States made the ruler advance from the state of decline to that of balance and progress, but the circle was governed by principles which assured a measure of external stability and public order. No sovereign could afford to violate these principles without the risk of losing the confidence of other sovereigns in the circle. Thus each sovereign had the sacred duty to respect the right of other dynasties to continuous existence. Debellatio (Latin "defeating, or the act of conquering") in case of defeat would have been a provocation of the circle, which would have risen against the violator of this right. Kautilya states that the just conqueror is satisfied with the obeisance of the defeated ruler. Thus the circle is, on the one hand, a dynamic vehicle for the unification of the sub-continent and, on the other, a guarantee of restraint on the part of the rulers and a means for the preservation of the balance of power (Alexandrowicz, 1965-1966: pp. 308-309). It is arguable that the "balance of power" maybe also an endorsement of internal diversity and pluralism. Just as in the current international humanitarian law of Hague Law (First Hague Peace Conferences, 1899; Second Hague Peace Conference, 1907) and Geneva Law (4 Geneva Conventions of 1949, 3 Additional Protocols) distinction as to non-combatants, hors de combat and surrendered of a warring party will determine the treatment by a capturing state.

\section{Is Vision of Pre-Colonial International Law Comparable to Western Style Sovereignty?}

From my analysis of the pre-colonial law of nations in India it is clear that rules in ancient India were put in place for the benefit of the ruler and were identified with religious expectations and demands. Further all the rules were to uplift the wealth ( $a r t h a$ ) of the ruler. In the pre-colonial India, values were pursued and fulfilled for the state as an institution of wealth. Within this overarching context room for the discretion of the ruler was left. This is very much similar to "lexhumana" of Aquinas who believed that law may be changed for human reason but maintaining that "an unjust law is not a law" as though it were an oxymoron (Kossel, in Pope (Ed.), 2002: pp. 191-192).

It is also clear that in pre-colonial India there were limited actors/participants (king and the priest) who made authoritative decisions which were discriminatory for the citizens, nonetheless such decisions were enforced by appealing to the religious mandatory duties of citizens to the advantage of the ruler (as citizens did all the jobs, from cultivation of crops to serving in the army). Nonperformance of these duties attracted sanctions. This clearly points out to the fact that the Hindu tradition of law was guided by religion and was sovereign focused just as western positivist law. Of course it is to be noted that the early positivist law was influence by the natural law principles and later Christian natural law principles but it still remained sovereign focused which is even true today and international law remains state centered with some exceptions in areas of human rights and individual criminal responsibility. Having said this the roots of international law were partly based on "jusnaturae" meaning that validity of international law is related to "Will of God" and sovereigns were seen as subject not only to divine law, but also to the laws of nature established by God. Most notable were Spanish theologians and jurists, such as Francisco de Vitoria (1486-1546), Francisco Suárez (1548-1617) and Dutch writer Hugo Grotius (1583-1645). In Grotius's (also called the founder of the Law of Nations) teachings natural law was a dominant element nonetheless he attempted to harmonize between doctrines of naturalism and positivism. In the broad sense then law in ancient India was a command of sovereign that is backed by sanctions and this process took place under a religious cover.

In the 19th Century, Lasswell \& McDougal rightly summarize that the dominant tradition of positivism which is derived from ancient Western-European thinking and strongly reinforced by certain basic presuppositions of the trans-empirical and positivistic emphases, has been that law is regarded "as an absolute and autonomous entity, independent of space and time, not related in any particular way to the nature of the society, in which it exists” (Lasswell \& McDougal, 1976: p. 476; Radcliffe-Brown, 1965: p. 198). In order to reject the metaphysical elements positivists concentrate more on the syntactic interconnections of such rules than their semantic dimen- 
sions of the interactions in which rules are employed (Lasswell \& McDougal, 1976: p. 471). It is clear that positivist ideas in India predates Westphalian international law and focuses on the nation-state sovereignty focusing on territoriality and non-intervention in the domestic affairs.

This leads me to another question that I initially raised "did India or for that matter other civilizations needed to be colonized in order to civilize them i.e. teach them western International law, before they could be decolonized?" It seems to me India did not need to be colonized to learn western style international law to make it civilized as similar values driven by wealth already existed. In this connection work of Gong (Gong, 1984), "standard of civilization", is useful. He argues that international law originated in Europe and was later applied throughout the world which disregarded the values of other civilizations especially colonies that were seen as inferior sovereignties. Non-European nations had to make adjustments to retain or earn their cultural diversity. On the other hand, Anghie (Anghie, 1999) argues that Westphalian understanding of sovereignty and suggests that Westphalian definition of sovereignty provide equality among Western States not non-Western world, which was considered as "uncivilized and hence non-sovereign". It is for this reason it was not possible to discuss pre-colonial visions on international law using the positivist methodology as they did not see non-European nations as equal but non-sovereign. However, Anghie in his work focusing on the relationship between positivism and colonialism (Anghie, 1999: p. 1) argues that after numerous colonial wars in 1914, virtually all the territories of Asia, Africa, and the Pacific were controlled by the major European states, resulting in the assimilation of all these non-European peoples into a system of law that was fundamentally European in that it derived from European thought and experience. Positivists at that time were faced with a problem, how can legal order be created among sovereign states? This appears inevitable, because the colonial confrontation was not a clash between two sovereign states, but between a sovereign European state and a non-European state under which the latter lacked sovereignty.

It is hence arguable that Eastern sovereignty was regarded as inferior as they did not fit in the definition of western sovereignty which governed relationship between two European/Christian sovereign states. The historical reality, as Alexandrowicz points out that all the major communities in India as well as elsewhere in the East Indies were politically organized; they were governed by their Sovereigns, they had their legal systems and lived according to centuries-old cultural traditions (Alexandrowicz, 1967: p. 14). In this connection it is asserted that the problem therefore for the positivist law was that there were no rules to allow the non-sovereign/colonial states into the Westphalian system, hence they came up with the rule of civilizing colonial nations for them to earn a place next to European sovereign nations through the process of decolonization. It is argued that aim was to usurp the wealth of colonies for their gain and it was disguised with a policy which provided them time to drain wealth (similar to Artha of Kautilya).

\section{Final Remark: Pre-Colonial Perspectives and Practices as Factors in Contemporary Indian International Law}

The psychology of the rise of Asia intensified with the 2008-09 financial crises and it became apparent that China is now playing a significantly central role in assuring financial and political stability (Ginsburg, 2010). With Japan already on the rise and now China and India joining it, there remains no uncertainty that Asia is a rising power and it will control share of world output and as such will have a say in global governance. Hence "Eastphalia" global order is rising against "Westphalia". Westphalia stands for principles of mutual noninterference, sovereignty and formal equality of states as derived from the Westphalian Peace Treaty 1648 which ended Thirty Years' War and the Eighty Years' War in Europe. If Eastphalia will materialize, it will insist on similar structures.

In 2009, an article title "Eastphalia Rising-Asian Influence and the Fate of Human Security" appeared in "World Policy Journal" and the authors, Kim, Fidler, and Ganguly, asserted that it no longer remains the point of debate whether China and India will affect the world politics rather point to discuss is "how" power migration to Asia (China \& India) will change global affairs as ideas are interlocked with power. Following the Second World War, it was the US and the Soviet Union that dominated the market and with extinction of Soviet Union, the US became ultimate heir of font of all "power and ideas" in global affairs. This is exactly what Kautilya's theory was how to control wealth (artha) which is a source of power for the king (sovereign) and how could it be used for balancing power within interstate affairs (Mandala).

This brings me to my final question: How do pre-colonial perspectives and practices bear on Contemporary 
Indian goals and practices? In view of the Eastphalia rising, which is the migration of power and influence towards Asia, how are Indian views on International law going to influence global affairs and the nations and people affected by these dramatic shifts. Keeping the above discussion in view the post-colonial India is a giant sized Asian secular democratic republic with impressive economic growth. It is increasingly seen as one of the impending regional powers (apart from China) (Emmott, 2008; Taylor Fravel, 2008), which has a potential to counter China's regional clout as an existing or imminent "superpower". Today with the shift of power to the east the concept of Eastphalian international order is a pan-Asian commitment to the concepts of inviolability of national sovereignty and non-intervention. The interplay of these ideas may define turns in peace, diplomacy and war and the concept of coexistence may transform the human security with the change of power (Kim, Fidler, \& Ganguly, 2009: pp. 53-64).

It is now clear that what was predicted by Kautilya in Arthashastra remains a global reality in contemporary times and interstate law and global affairs are guided by wealth (artha) and balance of power (Mandala). India as such should be a proud nation that its ancient scholar centuries ago prior to Western scholars' developed such a remarkable theory. As discussed in previous sections how India changed its policy from colonial to contemporary times, it is then arguable that value of wealth may continue to dominate the market for India. The world will seem to take a U-turn and focus will be on "Five Principles of Co-existence 1954" and ideas such as non-intervention and sovereignty will be driving force for material gain and wealth. This will put an end to brief interlude to European Universalism and global constitutionalism that intensified after the Second World War (Ginsburg, 2010: p. 27). There as such will be no room for intervention in states affairs even if such states are involved in human rights protection.

Carty and Lone (2011) in their article relying on Chimini’s (Chimini, 2010) work, described India’s approach to international relations as dualist. Dualism meant as opposition to the policies of imperialism at the same time as attempting to use existing international law to bring about change in the international system to the benefit of third world countries and particularly to their own benefit. This seems to be correct as India adopted "non-alignment" policy during the Cold War era to protect its own interest. The essential elements of dualism and Eastphalia, hence adopt the defensive, security oriented sovereignty that arose in Europe in the 17th Century and which has always been the basis of military as all as economic competition among the western powers (Carty \& Lone, 2011: p. 98).

At this stage keeping in view the "Eastphalian rising" and "dualist" arguments, rather preliminary conclusion could be drawn that India as an actor in the rising power game of Asia will continue to adopt a rather stringent "formalist dualist" attitude to its international disputes. Formalism suggests that there will be no substantive decisions to be made about law in relations to disputes as rules need merely to be applied on the facts to maintain status quo. It is then anticipated that Indian global affairs will be wealth (artha) driven which will have far reaching consequences for domestic civil rights protection movements that work on issues of human rights violations based on caste (untouchables), self-determination (Kashmir, Bengal and Assam) right to religion (Babri Majid Roits), and fight against poverty and corruption. If India is to become a future world power, her rather conservative attitude may destroy the expectations of billions of defenseless people who seek protection from the abuse of power by their own states.

\section{References}

Aiyangar, R. (1916). Ancient Indian Polity. Chennai: University of Madras.

Alexandrowicz, C. H. (1965-1966). Kautilyan Principles and the Law of Nations. British Yearbook of International Law, 41, 301.

Alexandrowicz, C. H. (1967). An Introduction to the History of the Law of Nations in the East Indies at 14.

Anghie, A. (1999). Finding the Peripheries: Sovereignty and Colonialism in Nineteenth-Century International Law. Harvard International Law Journal, 40, 1.

Baldridge, J. (2002). Linguistic and Social Characteristics of Indian English. Language in India, 2. http://www.languageinindia.com/junjul2002/baldridgeindianenglish.html

Boesche, R. (2002). The First Great Political Realist: Kautilya and His Arthashastra (Lexington Books).

Brekke, T. (2004). Wielding the Rod of Punishment-War and Violence in the Political Science of Kautilya. Journal of Military Ethics, 3, 40-52.

Carty, C., \& Lone, F. N. (2011). Some New Haven International Law Reflections on China, India and Their Various Terri- 
torial Disputes. Asia Pacific Law Review, 19, 93-111 at 96.

Chatterjee, H. (1958). International Law and Inter-State Relations in Ancient India.

Chaudhuri, S. (2009) The Tongues We Speak.

Chimini, B. S. (2010). International Law Scholarship in Post-Colonial India: Coping with Dualism. Leiden Journal of Inter-National Law, 23, 23-51.

Dossani, R. (2008). India Arriving: How This Economic Powerhouse is Redefining Global Business. New York: American Management Association.

Dossani, R. (2008). India Arriving: How This Economic Powerhouse is Redefining Global Business. New York: American Management Association.

Dumont, L. (1962). Conception of Kingship in Ancient India. Contributions to Indian Sociology.

Emmott, B. (2008). Rivals: How the Power Struggle between China, India and Japan will Shape our Next Decade. New York: Harcourt Inc.

Fravel, T. (2008). Strong Borders, Secure Nation. Princeton, NJ: Princeton University Press.

Ginsburg, T. (2010). Eastphalia as the Perfection of Wesphalia. Global Legal Studies, 17, 27.

Gonda, J. (1969) Ancient Indian Kingship from the religious Point of View. (Leiden,70)

Gong, G. W. (1984). The Standard of “Civilization” in International Society. Oxford: Clarendon Press.

Guha, R. (2007) India after Gandhi-The History of the World's Largest Democracy, Picador.

Kim, S. W., Fidler, D. P., \& Ganguly, S. (2009). Eastphalia Rising? Asian Influence and the Fate of Human Security. World Policy Journal, 26, 53-64. http://dx.doi.org/10.1162/wopj.2009.26.2.53

Kossel, C. G. (2002). Natural Law and Human Law. In S. J. Pope (Ed.), The Ethics of Aquinas. Washington, DC: Georgetown University Press.

Lasswell, H. D., \& Kaplan, A. (1950). Power and Society: A Framework for Political Inquiry.

Lasswell, H. D., \& McDougal, M. S. (1943). Legal Education and Public Policy: Professional Training in the Public Interest. Yale Law Journal, 52, 203-295. http://dx.doi.org/10.2307/792244

Lasswell, H. D., \& McDougal, M. S. (1976). The Relation of Law to Social Process: Trends in Theories about law. University of Pittsburgh Law Review, 37, 465-485.

Lasswell, H. D., \& McDougal, M. S. (1992). Jurisprudence for a Free Society: Studies in Law. Science and Policy, Volume I \& II, Leiden: Martinus Nijhoff Publishers.

Linghat, R. (1973). The Classical Law of India. (Translated from French with Additions by J. Duncan, \& M. Derrett, Berkeley, CA: University of California)

Lone, F. N. (2009). The Creation Story of Kashmiri People: The Right to Self-Determination. Denning Law Journal, 21, $1-25$.

McDougal, M. S., \& Lasswell. H. D. (1971). Criteria for a Theory about Law. Southern California Law Review, 44, 362-394, 376.

McDougal. M. S. (1953). International Law, Power, and Policy: A Contemporary Conception. Recueil des Cours, Hague Academy of International Law, 82, 133.

Moloney, P. (2011). Hobbes, Savagery, and International Anarchy. American Political Science Review, 105, $189-204$.

Nanda, V. P. (1991). International Law in Ancient Hindu India. In M. W. Janis (Ed.), The Influence of Religion on the Development of International Law. Leiden: Martinus Nijhoff Publishers.

Nayar, B. R., \& Paul, T. V. (2003). India in the World Order: Searching for Major-Power Status. Cambridge: Cambridge University Press.

Pan, J. W. (2011). Chinese Philosophy and International Law. Asian Journal of International Law, 1, 233-248.

Paulus. A. (2013). International Community in Max Planck Encyclopedia of Public International Law. http://opil.ouplaw.com

Penna, L. R. (1985). Traditional Asian Approaches: An Indian View. Australian Year Book of International Law, 9, 168.

Radcliffe-Brown (1965). Structure and Function in Primitive Society. 199. (Cited in Lasswell, H. D., \& McDougal, M. S. (1976). The Relation of Law to Social Process: Trends in Theories about Law, University of Pittsburgh Law Review, 37, 465-485.)

Reisman, W. M. (1992). The View from the New Haven School of International Law. In Proceedings of the American Society of International Law, 118, Paper 867.

Roy (2004) The Ordinary Person's Guide to Empire. Malton: Flamingo. 
Sarkar, B. K. (1919). Hindu Theory of International Relations. The American Political Science Review, 13, 400-414.

Shahabuddin, S. (2009) Approximate Muslim Population in India [2001]. The Milli Gazette (Indian Muslims’ Leading English Newspaper).

Sharma, R. S. (2008). Rethinking India's Past (OUP).

Singh, A. N., \& Singh, P. (2009). What Can International Law Learn from Indian Mythology, Hinduism and History? Journal of East Asia \& International Law, 2, 239-271.

Singh, B. (1964). The Sources of Contemporary Political Thought in India-A Reappraisal. Ethics, 75, 57-62.

Spellman, J. W. (1964). Political Theory of Ancient India.

Stein, O. (1921). Megasthenes and Kautilya.

Suzuki, E. (1974) The New Haven School of International Law: An Invitation to a Policy-Oriented Jurisprudence. Yale Studies in World Public Order, 1, 1.

Turmanidze, T. (2009) Buffer States: Power Policies, Foreign Policies and Concepts. New York: Nova Science Publishers.

Zhao, H. (2007) India and China: Rivals or Partners in Southeast Asia? Contemporary Southeast Asia, 29, 121-142. http://dx.doi.org/10.1355/CS29-1F 